\title{
Multicriteria Evaluation of Structural Composite Lumber Products
}

\author{
Hilal SINGER $^{1^{*}}$ Şükrü ÖZŞAHİN ${ }^{2}$ \\ ${ }^{I}$ Bolu Abant Izzet Baysal University, Faculty of Engineering, Department of Industrial Engineering, Golkoy Campus, Bolu, Turkey \\ ${ }^{2}$ Karadeniz Technical University, Faculty of Engineering, Department of Industrial Engineering, Kanuni Campus, Trabzon, Turkey
}

How to cite: Singer, H. \& Özşahin, Ş. (2020). Multicriteria evaluation of structural composite lumber products. J. Anatolian Env. and Anim. Sciences, 5(5), 807-813.

Atıf yapmak için: Singer, H. \& Özşahin, Ş. (2020). Yapısal kompozit kereste ürünlerinin çok kriterli değerlendirilmesi. Anadolu Çev. ve Hay. Dergisi, 5(5), 807-813.

(iD) : https://orcid.org/0000-0003-0884-2555

(iD : https://orcid.org/0000-0001-8216-0048

*Corresponding author's:

Hilal SINGER

Bolu Abant Izzet Baysal University, Faculty of Engineering, Department of Industrial

Engineering, Golkoy Campus, Bolu, Turkey. 凶: hilal.singer@hotmail.com

Mobile telephone: +90 (542) 4348968

Telephone : : $+90(374) 2541000 / 4902$ Fax $\quad:+90(374) 2534558$

\begin{abstract}
In this study, laminated veneer lumber, parallel strand lumber, and laminated strand lumber were evaluated via multicriteria decision-making methods. Within the model, nine evaluation criteria were defined: moisture content, density, bending strength, modulus of elasticity, compression strength parallel to grain, dynamic bending strength, tensile strength parallel to surface, tensile strength perpendicular to surface, and screw holding capacity. The weights of the criteria were computed using the fuzzy analytic hierarchy process (FAHP). The evaluation based on distance from an average solution (EDAS) and the technique for order preference by similarity to an ideal solution (TOPSIS) were employed to determine the ranking of the alternatives. After the borda count method was used, an integrated ranking was obtained. According to the results, the first three important subcriteria were density, bending strength, and modulus of elasticity. Furthermore, laminated veneer lumber was determined as the best alternative. Consequently, this study can present a road map to evaluate wooden materials.
\end{abstract}

Keywords: EDAS, FAHP, multicriteria decision-making, structural composite lumber, TOPSIS.

\section{Yapısal Kompozit Kereste Ürünlerinin Çok Kriterli Değerlendirilmesi}

*Sorumlu yazarın:

Hilal SINGER

Bolu Abant İzzet Baysal Üniversitesi,

Mühendislik Fakültesi, Endüstri Mühendisliği

Bölümü, Gölköy Kampüsü, Bolu, Türkiye.

$\triangle$ : hilal.singer@hotmail.com

Cep telefonu : $+90(542) 4348968$

Telefon : $+90(374) 2541000 / 4902$

Faks $\quad:+90(374) 2534558$
Öz: Bu çalışmada, tabakalanmış kaplama kereste, paralel şerit kereste ve tabakalanmış şerit kereste çok kriterli karar verme yöntemleri ile değerlendirilmiştir. Modelde dokuz değerlendirme kriteri belirlenmiştir: rutubet miktarı, yoğunluk, eğilme direnci, elastikiyet modülü, liflere paralel basınç direnci, dinamik eğilme direnci, yüzeye paralel yönde çekme direnci, yüzeye dik yönde çekme direnci ve vida tutma kabiliyeti. Kriterlerin ağırlıkları bulanık analitik hiyerarşi prosesi (BAHP) kullanılarak hesaplanmıştır. Alternatiflerin sıralamasını belirlemek için ortalama çözüm uzaklığına göre değerlendirme (EDAS) ve ideal çözüme benzerliğe göre tercih sıralama tekniği (TOPSİS) kullanılmıştır. Borda sayım yöntemi kullanıldıktan sonra birleşik bir sıralama elde edilmiştir. Sonuçlara göre, ilk üç önemli alt kriter yoğunluk, eğilme direnci ve elastikiyet modülüdür. Buna ilaveten, tabakalanmıș kaplama kereste en iyi alternatif olarak belirlenmiştir. Sonuç olarak, bu çalışma ahşap malzemelerin değerlendirilmesi için bir yol haritası sunabilir.

Anahtar kelimeler: BAHP, cok kriterli karar verme, EDAS, TOPSiS, yapısal kompozit kereste.

\section{INTRODUCTION}

Structural composite lumber (SCL) is a family of engineered wood products. It includes laminated veneer lumber (LVL), parallel strand lumber (PSL), laminated strand lumber (LSL), and oriented strand lumber (OSL) (Bayatkashkoli and Faegh, 2014). LVL is manufactured from wood veneers that are rotary peeled, dried, and laminated together with parallelly oriented grains under heat and pressure with an adhesive (Çolak et al., 2007). PSL is manufactured by adhesively bonding long, thin, and narrow strands of wood under high pressure (Arwade et al., 2010). LSL consists of oriented wood flakes that are glued and compressed to form panels up to $90 \mathrm{~mm}$ thick (Moses et al., 2003). OSL is similar to LSL. The SCL products are commonly used for rafters, headers, beams, joists, studs, 
and columns (APA, 2016). The advantages of SCL are high strength, flexibility, high stiffness, and excellent preservative treatability (Yazdani et al., 2004).

A large number of experimental studies have been conducted to evaluate the various properties of the SCL products (Ahmad \& Kamke, 2011; Arwade et al., 2010; Bal, 2016; Bayatkashkoli \& Faegh, 2014; Çolak et al., 2007; Çolak et al., 2019; Moses et al., 2003; Yazdani et al., 2004). In light of the experimental studies, it can be said that there are many factors that must be carefully evaluated. Therefore, it is important to use methods providing supportive and logical results in the evaluation process. Multicriteria decision-making (MCDM) methods can be used to evaluate decision elements. The fuzzy analytic hierarchy process (FAHP), the evaluation based on distance from an average solution (EDAS), and the technique for order preference by similarity to an ideal solution (TOPSIS) have been widely used to deal with decision-making problems and obtain quite reliable results (Chauhan \& Singh, 2016; Ecer, 2018; Karakuş et al., 2017). Therefore, in this study, these methods are used to evaluate the SCL products.

The MCDM methods have been efficiently applied to the various fields of wood science. Smith et al. (1995) employed the AHP method to analyze factors affecting the adoption of timber as a bridge material. Azizi (2008) selected the best wood supply alternative by employing the analytic network process (ANP) and the BOCR approach. Lipušček et al. (2010) employed the AHP method to classify wood products in terms of their impact on the environment. Azizi and Modarres (2011) selected the best construction panel by using the AHP and ANP methods. Azizi et al. (2012) used the AHP method to select the best medium density fiberboard (MDF) product. Kuzman and Grošelj (2012) compared different construction types by utilizing the AHP method. Sarfi et al. (2013) used the AHP method to analyze factors influencing the markets of particleboard and MDF. Karakuş et al. (2017) employed the TOPSIS method, the multiple attribute utility theory, and the compromise programing to predict the optimum properties of some nanocomposites. Singer and Özşahin $(2018,2020 a, 2020 b)$ prioritized some factors influencing the surface roughness of wood and wood-based materials in sawing, planing, and CNC machining. Özşahin et al. (2019) employed AHP and MOORA to select the best softwood species for construction.

Consequently, the literature review has demonstrated that there are many attempts on the use of MCDM methods for solving various decision-making problems in wood science. However, the literature has a gap in evaluating the SCL products by MCDM methods. Therefore, the objective of this study is to evaluate LVL,
PSL, and LSL by the MCDM analysis. In order to determine the priorities of the alternatives, an evaluation model containing FAHP, EDAS, and TOPSIS is proposed.

\section{MATERIALS AND METHODS}

Sample Preparation: The experimental data used in this study were obtained from the literature (Özçifçi et al., 2010; Sizüçen, 2008). The experimental process could be briefly explained as follows. Poplar (Populus tremula L.) veneers with the thickness of $3 \mathrm{~mm}$ were used to produce LVLs. Poplar (Populus tremula L.) strands were used to produce PSLs and LSLs. The size of strands in PSLs was $3 \mathrm{~mm}$ thick by $20 \mathrm{~mm}$ wide by $600 \mathrm{~mm}$ long. The size of strands in LSLs was $1.2 \mathrm{~mm}$ thick by $20 \mathrm{~mm}$ wide by $300 \mathrm{~mm}$ long. The veneers and strands were conditioned at a temperature of $55 \pm 2{ }^{\circ} \mathrm{C}$ and a relative humidity of $6 \pm 1 \%$ until they reached an average moisture content of 3\%. Phenol formaldehyde was chosen as the adhesive. It has density, viscosity, and $\mathrm{pH}$ value of 1.195 $1.205 \mathrm{~kg} / \mathrm{m}^{3}, 250-500 \mathrm{MPa}$ s, and 10.5-13, respectively. The materials were pressed for 7 minutes at a temperature of $180 \pm 3{ }^{\circ} \mathrm{C}$ and a pressure of $30 \mathrm{~kg} / \mathrm{cm}^{2}$ (ASTM D 5456, 1996). After pressing, the samples were conditioned at a temperature of $20 \pm 2{ }^{\circ} \mathrm{C}$ and a relative humidity of $65 \pm 5 \%$ (TS 642/ISO 554, 1997). The moisture content and density values of the samples were determined according to TS 2471 (1976) and TS 2472 (1976). The bending strength and modulus of elasticity tests were carried out according to the procedure of TS EN 310 (1999). The compression strength parallel to grain, dynamic bending strength, screw withdrawal, and tensile strength tests were carried out according to TS 2595 (1977), TS 2477 (1976), ASTM D 1761 (2000), and ASTM D 1037-06a (2006), respectively.

Fuzzy Sets and Fuzzy Numbers: The fuzzy set theory was developed by Zadeh (1965) in order to represent the uncertainty, vagueness, and ambiguity of judgments (Chauhan \& Singh, 2016). In the classical set theory, an element belongs or does not belong to a set. The element of a fuzzy set naturally belongs to the set with a membership value from the interval [0,1] (Kahraman \& Kaya, 2010). The most commonly utilized fuzzy numbers are triangular and trapezoidal fuzzy numbers. In this study, triangular fuzzy numbers (TFNs) will be employed owing to their ease of use. The following equation is the membership function of a TFN denoted as $(l, m, u)$ :

$\mu_{\widetilde{M}}(x)=\left\{\begin{array}{lr}0, & x<l \text { or } x>u \\ (x-1) /(m-1), & l \leq x \leq m \\ (u-x) /(u-m), & m \leq x \leq u\end{array}\right\}$

$l, m$, and $u$ indicate the lower value, the mid-value, and the upper value, respectively. The main arithmetic operations for two TFNs are as follows: 


$$
\begin{aligned}
& \widetilde{M}_{1} \oplus \widetilde{M}_{2}=\left(l_{1}+l_{2}, m_{1}+m_{2}, u_{1}+u_{2}\right) \\
& \widetilde{M}_{1} \otimes \widetilde{M}_{2}=\left(l_{1} l_{2}, m_{1} m_{2}, u_{1} u_{2}\right) \\
& \widetilde{\mathrm{M}}_{1}^{-1}=\left(1 / \mathrm{u}_{1}, 1 / \mathrm{m}_{1}, 1 / 1_{1}\right)
\end{aligned}
$$

The FAHP Method: AHP is a useful method to solve complex MCDM problems (Saaty, 1980). In the AHP method, the elements of the same level are compared in pairs with respect to an element located at the higher level. However, AHP is based on crisp judgments. In reality, it is very hard to acquire precise data owing to uncertainties on the judgments of decision-makers. Each decision-maker prefers natural language expressions rather than crisp numbers (Heo et al., 2010). Therefore, FAHP will be used to obtain the weights of the criteria. The steps of the FAHP method used in this study can be summarized as follows (Chang, 1996; Somsuk \& Laosirihongthong, 2014):

Step 1: The value of fuzzy synthetic extent with respect to the $i$ th object is computed.

$$
S_{i}=\sum_{j=1}^{m} M_{g_{i}}^{j} \otimes\left[\sum_{i=1}^{n} \sum_{j=1}^{m} M_{g_{i}}^{j}\right]^{-1}
$$

Step 2: The degree of possibility of $S_{i}=$ $\left(l_{i}, m_{i}, u_{i}\right) \geq S_{j}=\left(l_{j}, m_{j}, u_{j}\right)$ is calculated using the following equation:

$$
V\left(S_{i} \geq S_{j}\right)= \begin{cases}1, & m_{i} \geq m_{j} \\ 0, & l_{j} \geq u_{i} \\ \frac{l_{j}-u_{i}}{\left(m_{i}-u_{i}\right)-\left(m_{j}-l_{j}\right)}, & \text { otherwise }\end{cases}
$$

where $i=1,2, \ldots, n, j=1,2, \ldots m$, and $i \neq j$.

Step 3: The degree of possibility of $S_{\mathrm{i}}$ over all the other fuzzy numbers is calculated.

$$
\mathrm{V}\left(S_{i} \geq S_{j} \mid j=1,2, \ldots m ; i \neq j\right)=\min V\left(S_{i} \geq S_{j} \mid j=1,2, \ldots m ; i \neq j\right)
$$

Step 4: Compute the weight vector of a fuzzy matrix. Assume that $w_{i}^{\prime}=\min V\left(S_{i} \geq S_{j} \mid j=1,2, \ldots m ; i \neq\right.$ $j)$.

$$
w_{i}=\frac{w_{i}^{\prime}}{\sum_{i=1}^{n} w_{i}^{\prime}}
$$

Here, $w_{i}$ is a non-fuzzy value. The evaluation scale used in this study is given in Table 1 .

Table 1. The evaluation scale

\begin{tabular}{lc}
\hline Linguistic scale & Triangular fuzzy scale \\
\hline Equal & $(1,1,2)$ \\
Moderate & $(2,3,4)$ \\
Strong & $(4,5,6)$ \\
Very strong & $(6,7,8)$ \\
Extremely preferred & $(8,9,10)$
\end{tabular}

The EDAS Method: EDAS is a MCDM method that uses distances from average solutions $(A V)$. The evaluation of alternatives is carried out according to the higher values of the positive distance from the average $(P D A)$ and the lower values of the negative distance from the average (NDA). The EDAS procedure consists of the following steps (Keshavarz Ghorabaee et al., 2015):

Step 1: The decision matrix $D$ of $n$ alternatives and $m$ criteria is formed.

$D=\left[\begin{array}{cccc}x_{11} & x_{12} & \cdots & x_{1 m} \\ x_{21} & x_{22} & \cdots & x_{2 m} \\ \vdots & \vdots & \ddots & \vdots \\ x_{n 1} & x_{n 2} & \cdots & x_{n m}\end{array}\right]$

Step 2: $A V$ values are calculated.

$A V_{j}=\frac{\sum_{i=1}^{n} x_{i j}}{n}$

Step 3: The values of $P D A$ and $N D A$ are computed.

$$
\begin{gathered}
P D A_{i j}=\left\{\begin{array}{l}
\frac{\max \left(0,\left(x_{i j}-A V_{j}\right)\right)}{A V_{j}}, \text { if } j \in B \\
\frac{\max \left(0,\left(A V_{j}-x_{i j}\right)\right)}{A V_{j}}, \text { if } j \in N B
\end{array}\right. \\
N D A_{i j}=\left\{\begin{array}{l}
\frac{\max \left(0,\left(A V_{j}-x_{i j}\right)\right)}{A V_{j}}, \text { if } j \in B \\
\frac{\max \left(0,\left(x_{i j}-A V_{j}\right)\right)}{A V_{j}}, \text { if } j \in N B
\end{array}\right.
\end{gathered}
$$

$B$ and $N B$ are associated with benefit criteria and non-benefit criteria, respectively.

Step 4: The weighted sums of $P D A$ and $N D A$ are calculated with Equations (13) and (14).

$$
\begin{aligned}
& S P_{i}=\sum_{j=1}^{m}\left(w_{j} P D A_{i j}\right) \\
& S N_{i}=\sum_{j=1}^{m}\left(w_{j} N D A_{i j}\right)
\end{aligned}
$$

Here, $w_{j}$ is the weight of the $j$ th criterion.

Step 5: The normalized values of $S P$ and $S N$ are determined as follows:

$$
\begin{aligned}
N S P_{i} & =\frac{S P_{i}}{\max _{i}\left(S P_{i}\right)} \\
N S N_{i} & =1-\frac{S N_{i}}{\max _{i}\left(S N_{i}\right)}
\end{aligned}
$$

Step 6: The appraisal score $(A S)$ is calculated. 


$$
A S_{i}=\frac{N S P_{i}+N S N_{i}}{2}, \quad 0 \leq A S_{i} \leq 1
$$

The TOPSIS Method: TOPSIS is a MCDM method that obtains a solution which is closest to the positive ideal solution $(P I S)$ and farthest from the negative ideal solution (NIS). The TOPSIS procedure consists of the following steps (Hwang \& Yoon, 1981):

Step 1: The decision matrix is formed (see Equation (9)).

Step 2: The normalized decision matrix is obtained.

$r_{i j}=\frac{x_{i j}}{\sqrt{\sum_{i=1}^{n} x_{i j}^{2}}} i=1,2, \ldots, n ; j=1,2, \ldots, m$

Step 3: The weighted normalized decision matrix is obtained according to Equation (19).

$$
V_{i j}=w_{j} r_{i j}
$$

Step 4: PIS and NIS are determined using Equations (20) and (21), respectively.

$$
\begin{aligned}
& A^{+}=\left\{v_{1}^{+}, v_{2}^{+}, \ldots v_{n}^{+}\right\}=\left\{\left(\max v_{i j} \mid j \in B\right),\left(\min v_{i j} \mid j \in N B\right)\right\} \\
& A^{-}=\left\{v_{1}^{-}, v_{2}^{-}, \ldots v_{n}^{-}\right\}=\left\{\left(\min v_{i j} \mid j \in B\right),\left(\max v_{i j} \mid j \in N B\right)\right\}
\end{aligned}
$$

Step 5: Calculate the distance of alternatives from PIS and NIS.

$$
\begin{aligned}
& d_{i}^{+}=\sqrt{\sum_{j=1}^{m}\left(v_{i j}-v_{j}^{+}\right)^{2}} \\
& d_{i}^{-}=\sqrt{\sum_{j=1}^{m}\left(v_{i j}-v_{j}^{-}\right)^{2}}
\end{aligned}
$$

Step 6: The relative closeness to the ideal solution $\left(C_{i}\right)$ is computed.

$$
C_{i}=\frac{d_{i}}{d_{i}^{+}+d_{i}}
$$

The Borda Count Method: The borda count method can be employed to incorporate different ranking results. An alternative gets $m$ votes for the first-ranked criterion, $m-1$ votes for the second-ranked criterion, and 1 vote for the last-ranked criterion. The alternative with the largest sum of scores is the winner (Laukkanen et al., 2005).

Application: In the present study, a MCDM model is proposed to evaluate LVL, PSL, and LSL. This model consists of the following main phases: (1) prioritization of the criteria by FAHP, (2) prioritization of the alternatives by EDAS and TOPSIS, and (3) determination of the final ranking of the alternatives by Borda. The evaluation model is shown in Figure 1.

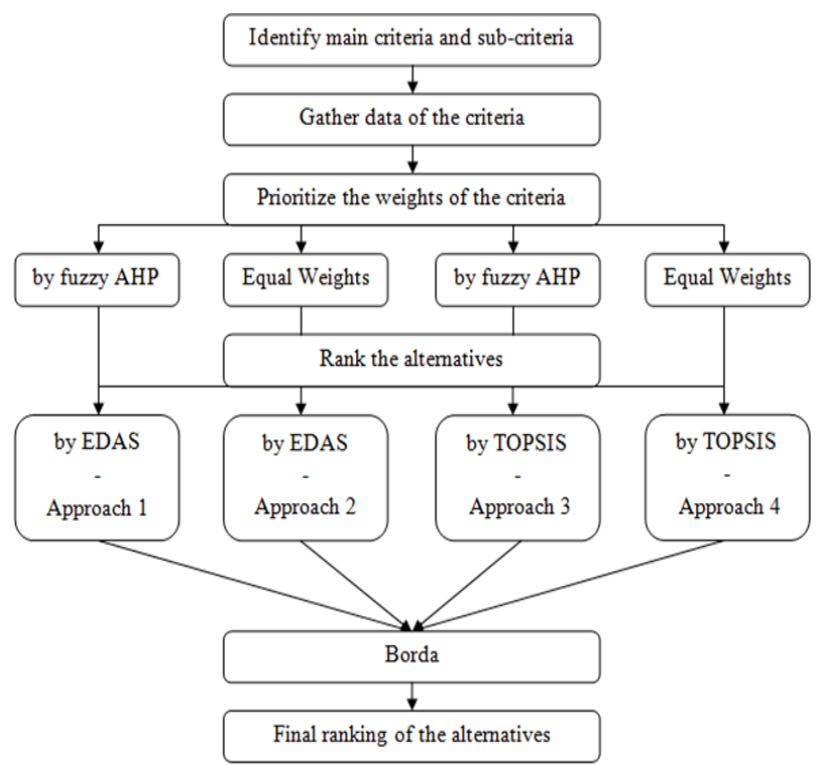

Figure 1. The evaluation model used in the study.

In order to evaluate the alternatives, two main criteria are defined as physical properties (PP) and mechanical properties (MP). The subcriteria of physical properties are moisture content (PP1) and density (PP2). The subcriteria of mechanical properties are bending strength (MP1), modulus of elasticity (MP2), compression strength parallel to grain (MP3), dynamic bending strength (MP4), tensile strength parallel to surface (MP5), tensile strength perpendicular to surface (MP6), and screw holding capacity (MP7). The hierarchical structure of the problem is portrayed in Figure 2.

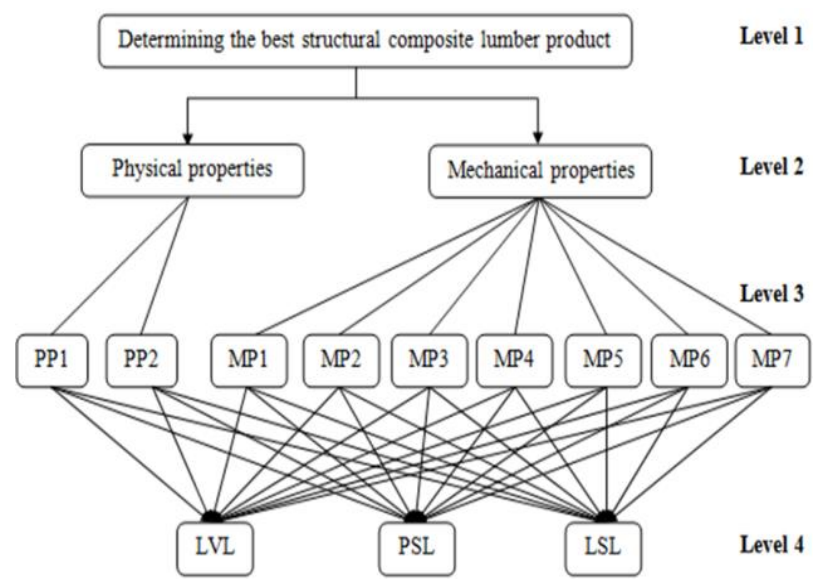

Figure 2. The decision hierarchy.

A decision-making team consisting of five experts who have experience with the research topic is constructed to evaluate each criterion. The experts use the linguistic terms (see Table 1) to compare the criteria. The linguistic terms are then converted to TFNs. The geometric means of 
the fuzzy values are computed to obtain the overall results of each evaluation matrix.

\section{RESULTS AND DISCUSSION}

The importance of each criterion is determined using FAHP. The comparison matrices can be seen from Tables 2-4.

Table 2. The comparison matrix of the main criteria.

\begin{tabular}{lcc}
\hline Criterion & PP & MP \\
\hline PP & $(1.000,1.000,1.000)$ & $(0.608,0.750,0.944)$ \\
MP & $(1.059,1.332,1.644)$ & $(1.000,1.000,1.000)$ \\
\hline
\end{tabular}

Table 3. The comparison matrix of the subcriteria within physical properties.

\begin{tabular}{lcc}
\hline Criterion & PP1 & PP2 \\
\hline PP1 & $(1.000,1.000,1.000)$ & $(0.758,0.903,1.217)$ \\
PP2 & $(0.822,1.108,1.320)$ & $(1.000,1.000,1.000)$ \\
\hline
\end{tabular}

Table 4. The comparison matrix of the subcriteria within mechanical properties.

\begin{tabular}{lccccccc}
\hline Criterion & \multirow{2}{*}{ MP1 } & \multirow{2}{*}{ MP2 } & \multirow{2}{*}{ MP3 } & \multirow{2}{*}{ MP4 } & \multirow{2}{*}{ MP5 } & \multirow{2}{*}{ MP6 } & \multirow{2}{*}{ MP7 } \\
\hline \multirow{3}{*}{ MP1 } & $(1.000$, & $(1.084$, & $(1.149$, & $(1.084,1$. & $(0.871$, & $(0.871$, & $(1.320$, \\
& 1.000, & 1.185, & 1.380, & 380, & 1.035, & 1.035, & 1.719, \\
& $1.000)$ & $2.000)$ & $2.169)$ & $1.741)$ & $1.431)$ & $1.431)$ & $2.491)$ \\
MP2 & $(0.500$, & $(1.000$, & $(1.246$, & $(0.922$, & $(1.059$, & $(1.059$, & $(1.320$, \\
& 0.844, & 1.000, & 1.476, & 1.246, & 1.246, & 1.246, & 1.719, \\
& $0.922)$ & $1.000)$ & $2.297)$ & $1.644)$ & $1.888)$ & $1.888)$ & $2.491)$ \\
MP3 & $(0.461$, & $(0.435$, & $(1.000$, & $(0.803$, & $(0.699$, & $(0.699$, & $(1.000$, \\
& 0.725, & 0.678, & 1.000, & 0.966, & 0.903, & 0.903, & 1.380, \\
& $0.871)$ & $0.803)$ & $1.000)$ & $1.320)$ & $1.320)$ & $1.320)$ & $1.888)$ \\
MP4 & $(0.574$, & $(0.608$, & $(0.758$, & $(1.000$, & $(0.944$, & $(0.944$, & $(1.084$, \\
& 0.725, & 0.803, & 1.035, & 1.000, & 1.185, & 1.185, & 1.476, \\
& $0.922)$ & $1.084)$ & $1.246)$ & $1.000)$ & $1.741)$ & $1.741)$ & $2.000)$ \\
MP5 & $(0.699$, & $(0.530$, & $(0.758$, & $(0.574$, & $(1.000$, & $(1.000$, & $(1.431$, \\
& 0.966, & 0.803, & 1.108, & 0.844, & 1.000, & 1.000, & 1.933, \\
& $1.149)$ & $0.944)$ & $1.431)$ & $1.059)$ & $1.000)$ & $2.000)$ & $2.433)$ \\
MP6 & $(0.699$, & $(0.530$, & $(0.758$, & $(0.574$, & $(0.500$, & $(1.000$, & $(1.431$, \\
& 0.966, & 0.803, & 1.108, & 0.844, & 1.000, & 1.000, & 1.933, \\
& $1.149)$ & $0.944)$ & $1.431)$ & $1.059)$ & $1.000)$ & $1.000)$ & $2.433)$ \\
MP7 & $(0.401$, & $(0.401$, & $(0.530$, & $(0.500$, & $(0.411$, & $(0.411$, & $(1.000$, \\
& 0.582, & 0.582, & 0.725, & 0.678, & 0.517, & 0.517, & 1.000, \\
& $0.758)$ & $0.758)$ & $1.000)$ & $0.922)$ & $0.699)$ & $0.699)$ & $1.000)$ \\
\hline
\end{tabular}

The weights are presented in Table 5. As seen in Table 5, mechanical properties (0.734) are more important than physical properties $(0.266)$. The most significant subcriterion is density $(0.147)$. Other important subcriteria are ranked as follows: bending strength $(0.132)$, modulus of elasticity (0.132), moisture content (0.119), tensile strength parallel to surface $(0.114)$, and tensile strength perpendicular to surface (0.112). The lowest priority value belongs to screw holding capacity (0.040). It is followed by compression strength parallel to grain (0.093).

Table 5. Summary of the weights.

\begin{tabular}{|c|c|c|c|c|}
\hline Main criterion & $\begin{array}{l}\text { Local } \\
\text { weight }\end{array}$ & Subcriterion & $\begin{array}{l}\text { Local } \\
\text { weight }\end{array}$ & $\begin{array}{l}\text { Global } \\
\text { weight }\end{array}$ \\
\hline \multirow{9}{*}{$\begin{array}{l}\text { Physical } \\
\text { properties } \\
\text { Mechanical } \\
\text { properties }\end{array}$} & \multirow[t]{2}{*}{0.266} & Moisture content & 0.448 & 0.119 \\
\hline & & Density & 0.552 & 0.147 \\
\hline & \multirow[t]{7}{*}{0.734} & Bending strength & 0.180 & 0.132 \\
\hline & & Modulus of elasticity & 0.180 & 0.132 \\
\hline & & $\begin{array}{l}\text { Compression strength } \\
\text { parallel to grain }\end{array}$ & 0.127 & 0.093 \\
\hline & & Dynamic bending strength & 0.151 & 0.111 \\
\hline & & $\begin{array}{l}\text { Tensile strength parallel to } \\
\text { surface }\end{array}$ & 0.156 & 0.114 \\
\hline & & $\begin{array}{l}\text { Tensile strength } \\
\text { perpendicular to surface }\end{array}$ & 0.152 & 0.112 \\
\hline & & Screw holding capacity & 0.054 & 0.040 \\
\hline
\end{tabular}

The decision matrix is given in Table 6. The physical and mechanical properties of the alternatives are evaluated by EDAS and TOPSIS. The results are presented in Tables 7 and 8. According to the results obtained by using the FAHP-EDAS approach, the best SCL product is LVL with an $A S$ of 0.693 . PSL with an $A S$ of 0.597 is positioned at the second rank, while LSL with an $A S$ of 0.491 is placed at the third rank. According to the results of the equal weighted EDAS analysis, the $A S \mathrm{~s}$ of LVL, PSL, and LSL are 0.776, 0.474 and 0.328, respectively. These values show that the best SCL product is LVL.

Table 6. The decision matrix

\begin{tabular}{|c|c|c|c|c|c|c|c|c|c|}
\hline & $\begin{array}{l}\text { PP1 } \\
(\%)\end{array}$ & $\begin{array}{c}\text { PP2 } \\
\left(\mathrm{g} / \mathrm{cm}^{3}\right)\end{array}$ & $\begin{array}{c}\text { MP1 } \\
\left(\mathrm{N} / \mathbf{m m}^{2}\right)\end{array}$ & $\begin{array}{c}\text { MP2 } \\
\left(\mathbf{N} / \mathbf{m m}^{2}\right)\end{array}$ & $\begin{array}{c}\text { MP3 } \\
\left(\mathrm{N} / \mathbf{m m}^{2}\right)\end{array}$ & $\begin{array}{c}\text { MP4 } \\
\left(\mathbf{k g m} / \mathrm{cm}^{2}\right)\end{array}$ & $\begin{array}{c}\text { MP5 } \\
\left(\mathrm{N} / \mathbf{m m}^{2}\right)\end{array}$ & $\begin{array}{c}\text { MP6 } \\
\left(\mathrm{N} / \mathbf{m m}^{2}\right)\end{array}$ & $\begin{array}{c}\text { MP7 } \\
\left(\mathrm{N} / \mathrm{mm}^{2}\right)\end{array}$ \\
\hline$\overline{\mathrm{LVL}}$ & 8.13 & 0.40 & 64.51 & 7907.2 & 49.87 & 0.46 & 25.97 & 805.01 & 6.10 \\
\hline PSL & 8.00 & 0.44 & 60.23 & 7864.6 & 43.85 & 0.50 & 25.88 & 796.66 & 5.46 \\
\hline LSL & 8.34 & 0.50 & 61.83 & 8022.5 & 41.91 & 0.40 & 26.04 & 775.88 & 5.89 \\
\hline
\end{tabular}

Table 7. The EDAS results

\begin{tabular}{cccccccccccccc}
\hline \multicolumn{1}{c}{ FAHP-EDAS } & & \multicolumn{5}{c}{ Equal weighted EDAS } \\
\hline LVL & 0.020 & 1.000 & 0.016 & 0.385 & 0.693 & 1 & & 0.025 & 1.000 & 0.012 & 0.552 & 0.776 & 1 \\
PSL & 0.014 & 0.705 & 0.013 & 0.490 & 0.597 & 2 & & 0.014 & 0.571 & 0.017 & 0.377 & 0.474 & 2 \\
LSL & 0.020 & 0.982 & 0.026 & 0.000 & 0.491 & 3 & & 0.016 & 0.656 & 0.027 & 0.000 & 0.328 & 3 \\
\hline
\end{tabular}

Table 8. The TOPSIS results

\begin{tabular}{|c|c|c|c|c|c|c|c|c|}
\hline \multicolumn{5}{|c|}{ FAHP-TOPSIS } & \multicolumn{4}{|c|}{ Equal weighted TOPSIS } \\
\hline & $\overline{d_{i}^{+}}$ & $d_{i}$ & $\overline{C_{i}}$ & Ranking & $d_{i}^{+}$ & $d_{i}$ & $\overline{C_{i}}$ & Ranking \\
\hline $\begin{array}{ll}\mathrm{LVL} \\
\end{array}$ & 0.020 & 0.014 & 0.419 & 3 & 0.015 & 0.017 & 0.518 & 1 \\
\hline PSL & 0.015 & 0.016 & 0.528 & 1 & 0.015 & 0.016 & 0.517 & 2 \\
\hline LSL & 0.018 & 0.019 & 0.520 & 2 & 0.019 & 0.015 & 0.448 & 3 \\
\hline
\end{tabular}

When the results of the FAHP-TOPSIS analysis are examined, it is seen that PSL $(0.528)$ is the best alternative. According to the results of the equal weighted TOPSIS analysis, the ranking of the SCL products in descending order with respective weights is $\operatorname{LVL}(0.518)>$ PSL (0.517) > LSL (0.448). Borda is employed due to different ranking results. Consequently, the ranking of the alternatives is as follows: $\{L V L-P S L-L S L\}$. In light of the results, it can be said that LVL is the best SCL product.

In Sizüçen's work, the experimental results of LVL, PSL, and LSL are reported. However, the ranking of them is not reported. This shortcoming is eliminated by the MCDM analysis.

\section{CONCLUSION}

The objective of this study is to evaluate LVL, PSL, and LSL by taking into account their physical and mechanical properties. In order to achieve the objective, an evaluation model containing FAHP, EDAS, and TOPSIS is proposed. FAHP is used to obtain the weights of the criteria. The weights are used in EDAS and TOPSIS to determine the ranking of the alternatives. Borda is employed to incorporate the ranking results. According to the results, the first three important subcriteria are density, 
bending strength, and modulus of elasticity. Moreover, it can be said that LVL possesses better properties when compared with PSL and LSL. Consequently, the evaluation model proposed in this study can provide beneficial insights for researchers in terms of the evaluation of wooden materials.

\section{ACKNOWLEDGMENTS}

The authors are thankful to Hamdullah Sizüçen for providing the experimental data used in this paper. The authors also acknowledge the experts for their contributions to this study. This study was presented in ORENKO 2020 held by Karadeniz Technical University, Trabzon.

\section{REFERENCES}

Ahmad, M. \& Kamke, F.A. (2011). Properties of parallel strand lumber from Calcutta bamboo (Dendrocalamus strictus). Wood Science and Technology, 45(1), 63-72.

APA. (2016). Engineered wood construction guide excerpt: structural composite lumber (SCL) selection and specification. The Engineered Wood Association, Washington.

Arwade, S.R., Winans, R. \& Clouston, P.L. (2010). Variability of the compressive strength of parallel strand lumber. Journal of Engineering Mechanics, 136(4), 405-412.

ASTM D 1037-06a. (2006). Standard test methods for evaluating properties of wood-base fiber and particle panel materials. ASTM Standards, USA.

ASTM D 1761. (2000). Standard methods of testing mechanical fastener in wood, staple or screw withdrawal test. ASTM Standards, USA.

ASTM D 5456. (1996). Standard specification for evaluation of structural composite lumber products. ASTM Standards, USA.

Azizi, M. (2008). A model of supplying poplar wood for Iranian paper \& wood factories. Journal of Forestry Research, 19(4), 323-328.

Azizi, M. \& Modarres, M. (2011). A decision making model for investment and development of construction panels. Journal of Forestry Research, 22(2), 301-310.

Azizi, M., Momeni, E. \& Mohebbi, N. (2012). Providing a decision-making model for importing mediumdensity fiberboard product. Journal of the Indian Academy of Wood Science, 9(2), 115-129.

Bal, B.C. (2016). Some technological properties of laminated veneer lumber produced with fastgrowing poplar and eucalyptus. Maderas. Ciencia y tecnología, 18(3), 413-424.

Bayatkashkoli, A. \& Faegh, M. (2014). Evaluation of mechanical properties of laminated strand lumber and oriented strand lumber made from poplar wood (populus deltoides) and paulownia (paulownia fortunei) with urea formaldehyde adhesive containing nanoclay. International Wood Products Journal, 5(4), 192-195.

Chang, D.-Y. (1996). Applications of the extent analysis method on fuzzy AHP. European Journal of Operational Research, 95(3), 649-655.

Chauhan, A. \& Singh, A. (2016). A hybrid multi-criteria decision making method approach for selecting a sustainable location of healthcare waste disposal facility. Journal of Cleaner Production, 139, 1001-1010.

Çolak, S., Çolakoğlu, G. \& Aydin, I. (2007). Effects of logs steaming, veneer drying and aging on the mechanical properties of laminated veneer lumber (LVL). Building and Environment, 42(1), 93-98.

Çolak, S., İlhan, O. \& Çolakoğlu, G. (2019). Effects of pressing time on some technological properties of laminated veneer lumber (LVL) produced using polythene waste as adhesive. Journal of Anatolian Environmental and Animal Sciences, 4(4), 662665.

Ecer, F. (2018). Third-party logistics (3Pls) provider selection via fuzzy AHP and EDAS integrated model. Technological and Economic Development of Economy, 24(2), 615-634.

Heo, E., Kim, J. \& Boo, K.J. (2010). Analysis of the assessment factors for renewable energy dissemination program evaluation using fuzzy AHP. Renewable and Sustainable Energy Reviews, 14(8), 2214-2220.

Hwang, C.L. \& Yoon, K. (1981). Multiple attribute decision making: methods and applications. Springer-Verlag, New York.

Kahraman, C. \& Kaya, İ. (2010). A fuzzy multicriteria methodology for selection among energy alternatives. Expert Systems with Applications, 37(9), 6270-6281.

Karakuş, K., Aydemir, D., Öztel, A., Gunduz, G. \& Mengeloglu, F. (2017). Nanoboron nitride-filled heat-treated wood polymer nanocomposites: comparison of different multicriteria decisionmaking models to predict optimum properties of the nanocomposites. Journal of Composite Materials, 51(30), 4205-4218.

Keshavarz Ghorabaee, M., Zavadskas, E.K., Olfat, L. \& Turskis, Z. (2015). Multi-criteria inventory classification using a new method of evaluation based on distance from average solution (EDAS). Informatica, 26(3), 435-451.

Kuzman, M.K. \& Grošelj, P. (2012). Wood as a construction material: comparison of different construction types for residential building using the analytic hierarchy process. Wood Research, 57(4), 591-600.

Laukkanen, S., Palander, T., Kangas, J. \& Kangas, A. (2005). Evaluation of the multicriteria approval method for timber-harvesting group decision support. Silva Fennica, 39(2), 249-264.

Lipušček, I., Bohanec, M., Oblak, L. \& Stirn, L.Z. (2010). A multi-criteria decision-making model for classifying wood products with respect to their 
impact on environment. The International Journal of Life Cycle Assessment, 15(4), 359-367.

Moses, D.M., Prion, H.G.L., Li, H. \& Boehner, W. (2003). Composite behavior of laminated strand lumber. Wood Science and Technology, 37(1), 5977.

Özçifçi, A., Uysal, B., Sizüçen, H., Yapıcı, F., Altun, S., Kurt, Ş. \& Özbay, G. (2010). A comparative study on some mechanical properties of structural composite lumbers (SCL) produced from poplar (Populus Tremula L.) papels. Technology, 13(2), 85-89.

Özşahin, Ş., Singer, H., Temiz, A. \& Yıldırım, İ. (2019). Selection of softwood species for structural and non-structural timber construction by using the analytic hierarchy process (AHP) and the multiobjective optimization on the basis of ratio analysis (MOORA). Baltic Forestry, 25(2), 281288.

Saaty, T.L. (1980). The analytic hierarchy process: planning, priority setting, resource allocation. McGraw-Hill, New York.

Sarfi, F., Azizi, M. \& Arian, A. (2013). A multiple criteria analysis of factors affecting markets of engineered wood products with respect to customer preferences: a case study of particleboard and MDF. Forest Science and Practice, 15(1), 61-69.

Singer, H. \& Özşahin, Ş. (2018). Employing an analytic hierarchy process to prioritize factors influencing surface roughness of wood and wood-based materials in the sawing process. Turkish Journal of Agriculture and Forestry, 42(5), 364-371.

Singer, H. \& Özşahin, Ş. (2020a). A multiple criteria analysis of factors influencing surface roughness of wood and wood-based materials in the planing process. Cerne, 26(1), 58-65.

Singer, H. \& Özşahin, Ş. (2020b). Prioritization of factors affecting surface roughness of wood and woodbased materials in CNC machining: a fuzzy analytic hierarchy process model. Wood Material Science \& Engineering, 1-9. DOI: 10.1080/17480272.2020.1778079

Sizüçen, H. (2008). Determination of some strength properties of laminated wood materials (LSL, LVL, PSL) produced from poplar strands. Master Thesis, Karabuk University, Turkey.

Smith, R.L., Bush, R.J. \& Schmoldt, D.L. (1995). A hierarchical model and analysis of factors affecting the adoption of timber as a bridge material. Wood and Fiber Science, 27(3), 225238.

Somsuk, N. \& Laosirihongthong, T. (2014). A fuzzy AHP to prioritize enabling factors for strategic management of university business incubators: resource-based view. Technological Forecasting \& Social Change, 85, 198-210.

TS 2471. (1976). Wood, determination of moisture content for physical and mechanical tests. Turkish Standards Institution, Ankara.
TS 2472. (1976). Wood, determination of density for physical and mechanical tests. Turkish Standards Institution, Ankara.

TS 2477. (1976). Wood, determination of impact bending strength. Turkish Standards Institution, Ankara.

TS 2595. (1977). Wood, determination of ultimate stress in compression parallel to grain. Turkish Standards Institution, Ankara.

TS 642/ISO 554. (1997). Standard atmospheres for conditioning and/or testing; specifications. Turkish Standards Institution, Ankara.

TS EN 310. (1999). Wood based panels, determination of modulus of elasticity in bending and of bending strength. Turkish Standards Institution, Ankara.

Yazdani, N., Johnson, E. \& Duwadi, S. (2004). Creep effect in structural composite lumber for bridge applications. Journal of Bridge Engineering, 9(1), 87-94.

Zadeh, L.A. (1965). Fuzzy sets. Information and Control, 8(3), 338-353. 